\title{
Retention and Tax Avoidance: \\ A Clarification
}

\section{Dan Palmon and Uzi Yaari}

Dan Palmon is Associate Professor of Accounting at Rutgers

University (Newark), and Uzi Yaari is Associate Professor of

Finance at Hofstra University.

\section{Introduction}

The literature of private and public finance offers three distinct claims associating retention of corporate earnings with personal tax avoidance. They are:

1. Distribution of earnings in the form of capital gains by methods such as stock repurchase and liquidation dividend entails smaller tax liability for investors than does distribution by cash dividends [7, 13].

2. Whether or not tax-saving distribution methods are used, financing of new investment by retention exposes shareholders only to the lower tax rate of capital gains $[20,37]$.

3. Retention is always preferable to cash dividends; a zero dividend is the superior policy because, even without the advantage of tax deferment, individual shareholders can realize through trading the full value of dividends forgone in the form of partially-exempt capital gains $[2,18]$.

An earlier draft of this paper containing additional sections on liquidation dividend and stock repurchase was presented in May 1978 at the Vincent $C$. Ross Institute for Accounting Research at New York University.
These claims appear to be inconsistent with observed behavior. Firms choose cash dividends far more frequently than stock repurchase or other distribution methods alleged to offer tax advantages. They often issue new stock simultaneously with the payment of dividend on outstanding stock. And they seldom reinvest all earnings.

This paper resolves part of the conflict between academic claims and observed behavior by challenging the conceptual validity of the last of the above contentions - hereafter referred to as the "substitution claim" - which states that the mere act of retention substitutes capital gains tax for dividend tax. We argue that rational investors view stock prices as a discounted value of cash flows net of tax, and therefore price appreciation due to retention should reflect a change in future dividends and the commensurate increase in future dividend tax. Consequently, any payment of capital gains tax - due to share trading among investors following retention - is added to the impact of dividend tax, not substituted for it. This 
argument holds regardless of which distribution method the firm chooses. For example, if eventual distribution is expected to take the form of stock repurchase, current stock price would reflect a reduced distribution tax rate. Nonetheless, given this tax advantage, if a decision to reinvest by deferring repurchase to some future date involves trading among investors to provide for the lost cash flow, it would add another layer of capital gains taxation rather than save any tax.

Unlike the first and second claims, where the tax advantage in avoiding dividends is stated in terms of a given investment plan, the third implies a change in both financial and investment plans. We show that an increase in reinvestment can benefit stockholders only if projects added have a return sufficient to cover taxes on the capital gains and dividends these projects will generate. It follows that the equilibrium reinvestment plan reflecting the effect of taxes should have included all such projects, thus eliminating any incentive for additional reinvestment.

\section{Background}

The substitution claim can be traced through the literature of public and corporate finance over half a century $[21,22,23,24$ (pp. 45-46), 30, 34, 35 (pp. 152-158), 38 (pp. 156-163)]. It often includes the following inferences:

1. Preferential tax treatment of capital gains, enhanced by the privilege of tax deferral, induces corporate saving and investment $[1,2,36,37]$. The incentive increases with the difference between dividend and capital gains tax rates [12, $16,17]$.

2. Tax-saving through retention should cause stocks of low payout ratio and dividend yield to sell at a premium price $[8,11,33]$.

3 . Retention results in under-taxation of corporatesource income which may cause over-investment in the corporate sector $[10,26$ (pp. 58-68), 31 (pp. 296-298)].

4. Tax consequences of retention are likely to create a tax clientele by attracting high-bracket taxpayers to low payout growth stocks $[6,25$, 28].

The potential tax benefit from converting ordinary income into capital gains is substantial when the percentage of capital gains excluded from taxation and marginal tax rates themselves are high, as they have been in recent decades. This led Elton and Gruber [13] to raise the question of why cash dividend rather than stock repurchase is the dominant distribution method. Their answer is that the net cost of repurchase, including tax and transaction costs, often exceeds that of paying dividends. The claimed implication for the firm's dividend policy of disparity between the two tax rates motivated Black and Scholes [8] to investigate the empirical relationship between dividend yield and market return unadjusted for tax. They found that stocks with low payout ratios did not sell at a premium, and rejected the hypothesis that shareholders prefer retention and its tax advantage on empirical grounds. They did not challenge the theoretical validity of the substitution claim, however. Moreover, their empirical tests fail to consider the possibility that a firm reinvesting only a portion of its earnings would nonetheless pursue a dividend-only distribution policy. They also ignore the capital gains tax involved when investors attain their cash objectives by trading stocks that have appreciated in price.

In seeking to explain the seemingly irrational preference of investors for dividends, Miller and Scholes [29] argued that a simple comparison of statutory tax rates overstates the disadvantage of income from this source. Their solution to the "dividend dilemma" lies in a combination of tax provisions which, under certain circumstances, may favor dividend income. First, there is the time-honored tax dodge of financing tax-favored investments by borrowing, while offsetting the resulting interest expense against income. In and of itself this device may reduce but not eliminate the tax advantage of capital gains; their partial exclusion requires a smaller amount of offsetting interest expense and less borrowing, thus calling for a smaller and less costly adjustment in the taxpayer's portfolio. The potential advantage of dividends comes from a second source: Section 163(d) introduced by the Tax Reform Act of 1975 restricts only the amount of capital gains against which interest expense can be offset. One difficulty with this hypothesis is that it does not explain the widespread payment of dividends prior to 1976. Another difficulty pointed out by Feenberg [15] lies in current tax data showing that the restriction imposed by Section 163(d) binds taxpayers receiving at most $3 \%$ of all dividend income.

In principle, one cannot rule out the possibility that effective devices of dividend tax arbitrage do exist. We argue that the existence of such devices would affect the choice between dividends and alternative distribution methods, not between distribution and reinvestment. 


\section{Tax Consequences of Future Distribution}

The substitution claim is particularly clear in Arditti et al. [1, p. 90]:

Since the firm should minimize the combined tax exposure to itself and its investors, it should adopt a zero dividend policy, that is, the stockholders pay the capital gains tax rather than the personal tax.

This claim is supported by a version of the following proof $[2,11]$. Denote the price per share at the beginning of year $i$ by $P_{1}$ and the pre-tax dividend per share paid at the end of the year by $D_{1+1}$. If the marginal personal tax rate on cash dividends is $\mathrm{t}^{\mathrm{D}}$ and on capital gains $t^{\mathrm{G}}$, the post-tax rate of return $r_{1}$ under the assumption of annual share trading is

$$
r_{1}=\frac{D_{1+1}\left(1-t^{D}\right)+\left(P_{i+1}-P_{i}\right)\left(1-t^{G}\right)}{P_{i}} .
$$

If a dollar diverted from $D_{1+1}$ to retained earnings adds a dollar to $P_{1+1}$ (namely $-\Delta D_{i+1}=\Delta P_{1+1}$ ) and therefore to $P_{i+1}-P_{i}$, it follows from the relationship $t^{D}>t^{G}$ that the rate of return is maximized by retaining all earnings, letting $D_{i+1}=0 .{ }^{1}$

The substitution claim hinges on the often hidden assumption that "the fraction of after-tax earnings not paid out as dividends results in an equivalent increase in the firm's equity value" [2, p. 47]. This standard assumption, also explicit in [18], is consistent only with investment equilibrium in an environment free of personal taxes. It ignores a fundamental feature of a world like ours, in which prices, and therefore price changes caused by retention, should fully reflect tax consequences of future distributions. Granted that investors expect all distributions to be taxed, whether at $\mathrm{t}^{\mathrm{D}}$ or $\mathrm{t}^{\mathrm{G}}$, if retention of a dollar adds a dollar to the discounted value of future pre-tax distributions - which may not be an equilibrium condition any more - it should add only a fraction of a dollar to $P_{i+1}$.

\footnotetext{
${ }^{1}$ Note that the assumed condition $-\Delta D_{i+1}=\Delta P_{1+1}$ is sufficient but not necessary for the alleged profitable substitution; the necessary condition is $\left|D_{1+1}\left(1-t^{D}\right)\right|<\left|\Delta P_{1+1}\left(1-t^{G}\right)\right|$. Also note that this proof is derived under the unfavorable assumption that shareholders sell their entire holding at the end of the year. Based on this logic, it can be shown that retention would be advantageous even if $\mathrm{t}^{\mathrm{D}}=\mathrm{t}^{\mathrm{G}}$, under the assumption that shareholders sell only the minimum necessary to duplicate the dividend stream obtained under full distribution. This is one way of looking at the advantage of capital gains tax deferral. A different version of the same proof can be found in $[5,18$, and 31 (ftn. 32)], where the effective personal tax rate is presented as a weighted average of dividend and capital gains taxes $(1-b) t^{D}+b t^{G}$, with $b$ representing the fraction of earnings retained.
}

Failure to distinguish between the effect of retention on shareholders' current tax liability and its claimed effect on the impact of dividend tax is tantamount to equating the combination of corporate retention and gains realized in individual share trading to a taxsaving distribution method. This seems to be the essence of the following statement by Modigliani and Miller [30, ftn. 57], recited by Miller [27, p. 266]:

[A company] can invest in the business all of its net income and to this extent subject the owners only to the low capital gains rate (or possibly no tax at all by virtue of the loophole at death). (Emphasis added.)

This statement contains unambiguous reference to real investment and does not make tax avoidance contingent upon the existence of an effective tax-saving distribution method. Rather, it depicts a scenario of perpetual corporate expansion combined with welltimed individual share trading.

Similar thoughts are expressed in a recent paper by Auerbach [3, p. 293]:

Thus, all firms' receipts, coming from profits and the sale of new shares, will either be distributed as dividends or retained and reinvested in new capital. Our results indicate that the superiority of gains over dividends as a method of distribution depends on the valuation of a share of stock. (Emphasis added.)

Like the previous statement, this one does not specify a given investment policy where one distribution method is substituted for another; on the contrary, it explicitly refers to the combination of new investment and realization of capital gains in subsequent trading as "distribution."

\section{Consistency with Equilibrium}

The crucial assumption underlying the substitution claim, of dollar-for-dollar tradeoff between dividend and share price, is challenged under the following set of simplifying assumptions.

1. Cash dividend, the most common method, is the only one used. The issue at hand is whether tax can be saved by increasing investment through retention under a given distribution method, not by switching to alternative methods under a given investment policy. Exclusion of other methods serves to eliminate ambiguity regarding tax consequences of future distribution. (Models describing tax effects of stock repurchase on valuation are found in $[7,13$, and 32].)

2. Firms may not increase the proportion of financial assets in their asset portfolio. This assumption is designed to circumvent mutual 
back-scratching by corporations through crossownership, a substitute for stock repurchase. A firm's purchase of corporation stock, including its own, results in net distribution for the corporate sector and should be considered as distribution rather than investment in terms of its tax consequences. The assumed effective limitation on this form of investment is consistent with the lack of any trend toward greater liquidity in the non-financial sector. It is also consistent with the substitution claim which does not limit reinvestment to financial assets.

3. Tax arbitrage is imperfect, leaving a nonnegligible effective rate of dividend tax.

4. The effective marginal rate of dividend tax paid by the marginal investor is expected to remain constant.

5. The firm is financed exclusively by equity, with retention being the source of funds used at the margin. The latter requirement is consistent with conditions under which the effective rate of capital gains tax is not higher than that paid on distributed earnings and is relevant for the issue at hand.

With this set of assumptions, it is easier to see why the assumption that a dollar retained results in a full dollar of capital gains is inconsistent with equilibrium conditions. Since equilibrium implies a marginal investment yield equal to the firm's cutoff rate, a decision to retain a dollar of earnings should leave the current share price unchanged and therefore be a matter of indifference to owners. This condition is met only if the price increase is of the same post-tax value as the distribution forgone - a requirement inconsistent with the assumption of pre-tax dollar-for-dollar tradeoff between $D_{1+1}$ and $P_{1+1}$ implying inequality of post-tax values $\left|\Delta D_{1+1}\left(1-t^{D}\right)\right|<\mid \Delta P_{i+1}$ $\left(1-t^{G}\right) \mid$.

\section{Investment and Financial Equilibrium}

To show that the substitution claim contradicts conventional precepts of investment equilibrium, we can add the following simplifying non-restrictive assumptions to those stated above.

1. Investment opportunities in any period are subject to diminishing return.

2. Future investment opportunities are independent of the firm's current investment. ${ }^{2}$

${ }^{2}$ As shown by Elton and Gruber [14] and Gordon and Gould [20], investment equilibrium conditions are affected by the nature of inter-temporal dependence of the investment function. The assumption of independence does not affect the main conclusions.
3. Capital gains tax rate is set at zero. According to the substitution claim, this should allow complete avoidance of personal taxes through a full retention policy.

The firm's investment equilibrium is illustrated in the exhibit, where the pre-tax marginal rate of return schedule is denoted by $y$, shareholder net-of-tax opportunity rate of return by $r$, and the rates of corporate profit tax and dividend tax by $\mathrm{t}^{\mathrm{C}}$ and $\mathrm{t}^{\mathrm{D}}$, respectively. Equilibrium conditions imply that shareholders cannot benefit from changing the investment plan. Equality between the cost and benefit associated with any change in investment is reached at the intersection of the decreasing marginal schedule $y\left(1-t^{C}\right)$ with the constant $\mathbf{r}$. Indicated by the capital stock $\mathrm{K}^{\mathrm{c}}$, this intersection implies equality between exogenous net-of-tax marginal cost $\mathrm{r}$ and post-corporate-tax marginal benefit $y\left(1-t^{\mathrm{C}}\right)$. That the firm prefers $\mathrm{K}^{\mathrm{C}}$ over the intuitively appealing $\mathrm{K}^{\mathrm{D}}$, at which the two post-personal-tax rates are equalized $\left[\mathrm{r}=\mathrm{y}\left(1-\mathrm{t}^{\mathrm{C}}\right)\right.$ $\left.\left(1-t^{D}\right)\right]$, is because it can retain and reinvest earnings not subject to dividend tax. From the point of view of the investor, the opportunity cost of undistributed earnings is at the rate $r\left(1-t^{D}\right)$ rather than $r$, which must be equated to the rate of marginal benefit $y\left(1-t^{C}\right)\left(1-t^{D}\right)$. The equality $r\left(1-t^{D}\right)=y\left(1-t^{C}\right)$ $\left(1-t^{D}\right)$ on a post-personal-tax basis at the shareholder level is consistent with the equality $r=y\left(1-t^{C}\right)$ on a pre-personal-tax basis at the level of the firm.

The exhibit gives rise to a number of interesting implications bearing upon the substitution claim and related issues. First, the equilibrium equality $r=$ $y\left(1-t^{c}\right)$ indicates that with a zero capital gains tax

\section{Exhibit. Investment Equilibrium with Taxes}

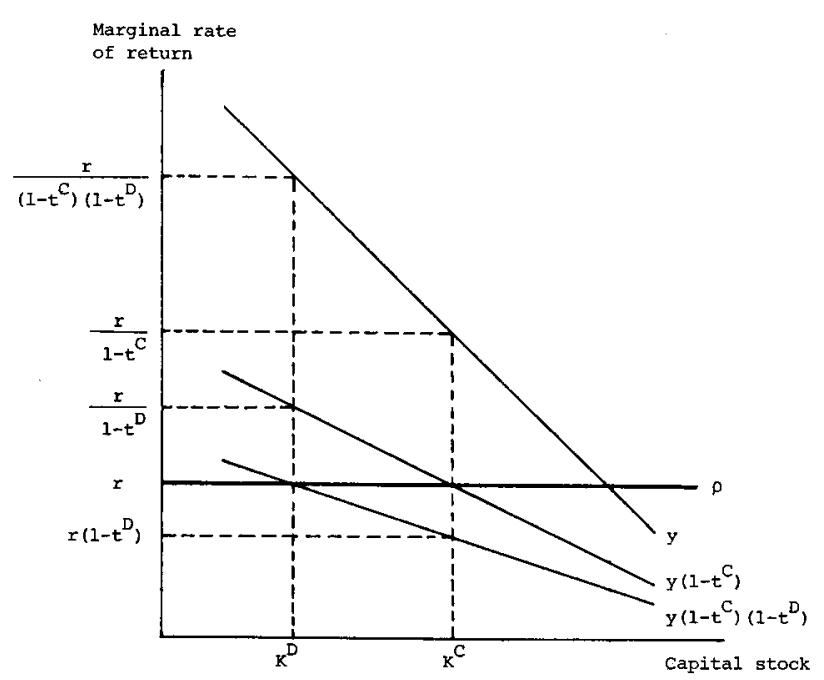


rate and inter-temporal independence of the investment function, the firm's post-corporate-tax cutoff rate for internal funds equals the shareholder net-oftax opportunity rate of return: $\rho=\mathrm{r}^{3}$ Second, this cutoff rate and the implied optimal investment and dividend policies are not affected by the rate of dividend tax. (Bradford [9] arrives at a similar conclusion by forcing $\rho=r$ through the assumptions of constant $y$, $t^{\mathbf{C}}=0$, and therefore $\mathrm{r}=\mathrm{y}$.) Because of the assumption of diminishing return, equilibrium investment and dividend policies are unique, where the latter is ensured by the additional assumptions of absence of debt financing and strict preference for internal financing as $t^{\mathrm{D}}>\mathrm{t}^{\mathrm{G}}$.

In view of the important role played by the assumption of diminishing return in deriving the above results, it remains to determine the effect of adopting instead the assumption of unlimited investment opportunities at a constant return, which underlies the substitution claim. Specifically, it could be argued that returns diminish at the industry level but are perceived as constant by the individual firm. In terms of the exhibit, firm equilibrium consistent with that of the industry would then be achieved at an arbitrary point along a constant schedule $y\left(1-t^{\mathrm{C}}\right)$ at the level $r$. Such equilibrium would imply indifference toward retention consistent with the Modigliani-Miller tax-free hypothesis $[28,30]$, but not with the preference for retention according to the substitution claim. The main difficulty in accepting the notion of a constant return at the rate $y\left(1-t^{\mathrm{C}}\right)$ equal to $r$ lies in another empirical implication. Because the cost of external funds, $r /\left(1-t^{D}\right)$, is always higher than $r$, it is implied that, once the dividend tax is in effect, stock issuance by established or new corporations will never be profitable. ${ }^{4}$ In contrast, under the decreasing $y$ schedule in the exhibit, stock issuance is justified as a means of financing investment of abnormal pre-tax yield exceeding $y=r /\left[\left(1-t^{C}\right)\left(1-t^{D}\right)\right]$ for which there are insufficient internal funds. Similarly, limited investment opportunities yielding such a high rate of return are necessary and sufficient to attract new corporate enterprises.

\footnotetext{
${ }^{3}$ In the presence of capital gains tax at the effective rate $t^{\mathrm{G}}<\mathrm{t}^{\mathrm{D}}$, the cutoff rate for internal funds assumes the familiar form $r /\left(1-t^{G}\right)$, and equilibrium in the exhibit is reached at the intersection $\mathrm{r} /\left(1-\mathrm{t}^{\mathrm{G}}\right)=\mathrm{y}\left(1-\mathrm{t}^{\mathrm{C}}\right)$, implying optimal level of capital stock smaller than $\mathrm{K}^{\mathrm{C}}$. This cutoff rate is derived under a different set of assumptions in [4 and 20].
}

\section{Non-Growth Firm: A Special Case}

The above results can be easily applied to the special case of the non-growth firm. Consider an attempt to reduce the impact of dividend tax by avoiding distribution in the current year with the intention of paying a larger annuity thereafter. If current post-corporate-tax earnings per share, $D$, can be reinvested at $\rho=\mathrm{r}$, the increased stream of dividends expected to begin next year is $D(1+r)$, and the post-dividend-tax cash flow $\mathrm{D}(\mathrm{I}+\mathrm{r})\left(1-\mathrm{t}^{\mathrm{D}}\right)$. In the absence of capital gains tax, the ex-dividend price anticipating such a policy is

$$
\begin{aligned}
P_{0} & =\frac{1}{1+r} \cdot \frac{D(1+r)\left(1-t^{D}\right)}{r} \\
& =\frac{D\left(1-t^{D}\right)}{r}
\end{aligned}
$$

indicating no change from the price that would prevail in anticipation of no retention. This result is uilavoidable if earnings are reinvested and discounted at the same rate of interest $r$. Viewed from another perspective, the ex-retention price which can be realized at the end of the year without paying additional tax (no capital gains tax), $D(1+r)\left(1-t^{D}\right) / r$, is precisely the sum of the post-tax dividend $D\left(1-t^{D}\right)$ and the ex-dividend price $D\left(1-t^{D}\right) / r$ which could be realized at that time without retention. ${ }^{5}$ It is apparent that avoiding retention would actually be to the shareholders' benefit if investment beyond the equilibrium level yields less than $\mathbf{r}$, or if capital gains are subject to $\operatorname{tax}$.

To illustrate the latter case, assume, as in Equation (1), that the marginal shareholding is traded at annual intervals following retention or distribution and that realized capital gains, if any, are taxed at the effective rate $t^{\mathrm{G}}$. (As numerous authors have argued, the effective rate of capital gains tax is reduced by deferred trading.) Market equilibrium sets the valuation condition

$$
(1+r) P_{0}=D\left(1-t^{D}\right)+P_{1}-\left(P_{1}-P_{0}\right) t^{G}
$$

simplified by the assumed $\mathrm{D}=0$ to

$$
(1+r) P_{0}=P_{1}-\left(P_{1}-P_{0}\right) t^{G}
$$

${ }^{5}$ The effect of distribution tax on capital losses is symmetrical to its effect on capital gains. The capital loss on ex-dividend day $D\left(1-t^{D}\right)$ fully reflects the effect of dividend tax on future distribution forgone. 
Since the absence of growth beyond the current year implies no additional payment of capital gains tax despite annual trading, the ex-retention price at the end of the current year is still $P_{1}=D(1+r)\left(1-t^{D}\right) / r$. Substitution of this value in Equation (4) yields after rearrangement

$$
P_{0}=\frac{D\left(1-t^{D}\right)}{r}-\frac{D\left(1-t^{D}\right) t^{G}}{1+r-t^{G}}
$$

where the second term represents additional tax impact resulting from retention, implying strict preference for distribution.

\section{Distribution Tax and}

\section{Investment Equilibrium: A Second Look}

Further challenge to the substitution claim focuses on its implication of a positive relationship between the dividend tax rate and the incentive to reinvest earnings. The argument accommodates growth but requires the non-restrictive assumptions of exclusive internal financing and annual share trading. Given arbitrary sequences of dividends $D_{i}$ and discount rates $r_{1}$ $(\mathrm{i}=1,2, \ldots)$, the ex-dividend price can be derived by repeated substitution of the sequence of future prices in Equation (3):

$$
P_{0}=\sum_{i=1}^{\infty} \frac{D_{i}\left(1-t^{D}\right)\left(1-t^{G}\right)^{1-1}}{\prod_{j=1}^{i}\left(1+r_{j}-t^{G}\right)}
$$

Since this price is a fixed fraction $1-t^{D}$ of the predividend-tax current value of all distributions, maximization of the latter implies maximization of the former. It follows that, with exclusive internal financing, the firm's optimal distribution and investment policies - whether unique or not - are independent of the rate of dividend $\operatorname{tax}^{6}$ But this rules out the possibility of deriving benefit from increased reinvestment in the presence of this tax.

\section{Conclusion}

This paper has sought to dispel a commonly-held belief that, with preferential tax treatment of capital gains, any amount of earnings retained by the corporation will reduce shareholders' tax exposure.

${ }^{6}$ It can be shown that an increase in dividend tax causes curtailment of investment if the firm uses external financing, as does an increase of capital gains tax under internal financing (see ftn. 3).
Nowhere in this paper is it implied that retention may not be the best source of funds for financing a given investment, or that tax laws are irrelevant for determining the optimal level of investment. The point stressed is that an increase in investment tends to increase the impact of personal taxes even when financed by retention, such that, if all projects satisfying shareholders' post-tax return requirements have been taken, reinvesting additional funds would be to their detriment.

\section{References}

1. F. D. Arditti, H. Levy, and M. Sarnat, "Taxes, Capital Structure, and the Cost of Capital: Some Extensions," Quarterly Review of Economics and Business (Summer 1977), pp. 89-95.

2. F. D. Arditti, H. Levy, and M. Sarnat, "Taxes, Uncertainty, and Optimal Dividend Policy," Financial Management (Spring 1976), pp. 46-52.

3. A. J. Auerbach, "Share Valuation and Corporate Equity Policy," Journal of Public Economics (June 1979), pp. 291-305.

4. A. J. Auerbach, "Wealth Maximization and the Cost of Capital," Quarterly Journal of Economics (August 1979), pp. 433-446.

5. M. J. Bailey, "Capital Gains and Income Taxation," in A. C. Harberger and M. J. Bailey, eds., Taxation of Income from Capital, Washington, D.C., The Brookings Institution, 1969.

6. M. J. Bailey, "Progressivity and Investment Yields under U.S. Income Taxation," Journal of Political Economy (November/December 1974), pp. 1157-1175.

7. H. Bierman and R. West, "The Acquisition of Common Stock by the Corporate Issuer," Journal of Finance (December 1966), pp. 687-696.

8. F. Black and M. Scholes, "The Effects of Dividend Yield and Dividend Policy on Common Stock Prices and Returns," Journal of Financial Economics (May 1974), pp. 1-22.

9. D. F. Bradford, "The Incidence and Allocation Effects of a Tax on Corporate Distributions," forthcoming in Journal of Public Economics.

10. G. Break and J. A. Pechman, "Relationship Between the Corporation and Individual Income Taxes," National Tax Journal (September 1975), pp. 341-352.

I1. M. J. Brennan, "Taxes, Market Valuation and Corporate Financial Policy," National Tax Journal (December 1970), pp. 417-427.

12. J. A. Brittain, Corporate Dividend Policy, Washington, D.C., The Brookings Institution, 1966.

13. J. E. Elton and M. Gruber, "The Effect of Share Repurchase on the Value of the Firm," Journal of Finance (March 1968), pp. 135-149.

14. J. E. Elton and M. Gruber, "Valuation and Asset Selection under Alternative Investment Opportunities," Journal of Finance (May 1976), pp. 525-539. 
15. D. Feenberg, "Does the Investment Interest Limitation Explain the Existence of Dividends?" National Bureau of Economic Research, Working Paper Series No. 530, 1980.

16. M. S. Feldstein, "Corporate Taxation and Dividend Behaviour," Review of Economic Studies (January 1970), pp. 57-72.

17. M. S. Feldstein and D. Frisch, "Corporate Tax Integration: The Estimated Effects of Capital Accumulation and Tax Distribution of Two Integration Proposals," National Tax Journal (March 1977), pp. 37-52.

18. M. S. Feldstein, J. Green, and E. Sheshinski, "Corporate Financial Policy and Taxation in a Growing Economy," Quarterly Journal of Economics (August 1979), pp. 411-432.

19. I. Fisher, Constructive Income Taxation, New York, Harper and Brothers Publications, 1942.

20. M. J. Gordon and L. I. Gould, "The Cost of Equity Capital with Personal Income Taxes and Flotation Costs," Journal of Finance (September 1978), pp. 1201-1212.

21. R. M. Haig, "The Concept of Income - Economic and Legal Aspects," in R. M. Haig, ed., The Federal Income Tax, New York, Columbia University Press, 1921.

22. R. M. Haig, "Taxation of Capital Gains," Wall Street Journal, March 29, 1937.

23. A. C. Harberger, "The Incidence of the Corporation Income Tax," Journal of Political Economy (June 1962), pp. 215-240.

24. N. Kaldor, An Expenditure Tax, London, George Allen and Unwin, 1955.

25. R. H. Litzenberger and K. Ramaswamy, "The Effect of Personal Taxes and Dividends on Capital Asset Prices: Theory and Empirical Evidence," Journal of Financial Economics (June 1979), pp. 163-195.
26. J. E. Meade (chairman), The Structure and Reform of Direct Taxation, London, George Allen and Unwin, 1978. Report of a committee at The Institute for Fiscal Studies.

27. M. H. Miller, "Debt and Taxes," Journal of Finance (May 1977), pp. 261-275.

28. M. H. Miller and F. Modigliani, "Dividend Policy, Growth and the Valuation of Shares," Journal of Business (October 1961), pp. 411-433.

29. M. H. Miller and M. Scholes, "Dividends and Taxes," Journal of Financial Economics (December 1978), pp. 333-364.

30. F. Modigliani and M. H. Miller, "The Cost of Capital, Corporation Finance and the Theory of Investment," American Economic Review (June 1958), pp. 261-297.

31. R. A. Musgrave and P. B. Musgrave, Public Finance in Theory and Practice, New York, McGraw-Hill Book Company, 1976.

32. D. Palmon and U. Yaari, "Stock Repurchase as a TaxSaving Distribution," forthcoming in Journal of Financial Research.

33. R. R. Pettit, "Taxes, Transaction Costs and the Clientele Effect of Dividends," Journal of Financial Economics (December 1977), pp. 419-436.

34. A. G. Pigou, "The Report of the Royal Commission on the British Income Tax," Quarterly Journal of Economics (August 1920), pp. 607-625.

35. H. C. Simons, Personal Income Taxation, Chicago, University of Chicago Press, 1938.

36. R. C. Stapleton, "Taxes, the Cost of Capital and the Theory of Investment," Economic Journal (December 1972) pp. 1273-1292.

37. J. Stiglitz, "Taxation, Corporate Financial Policy, and the Cost of Capital," Journal of Public Economics (February 1973), pp. 1-34.

38. W. Vickrey, Agenda for Progressive Taxation, New York, The Ronald Press Company, 1947. 